\title{
Analysis of RAD51C germline mutations in high- risk breast and ovarian cancer families and ovarian cancer patients
}

\author{
ER Thompson ${ }^{*}$, SE Boyle ${ }^{1}$, J Johnson ${ }^{2,3}$, GL Ryland ${ }^{1,4}$, S Sawyer ${ }^{1}$, DY Choong ${ }^{1}$, kConFab ${ }^{1}$ G Chenevix-Trench², \\ AH Trainer ${ }^{1}$, GJ Lindeman ${ }^{5,6}$, G Mitchell $^{1}$, PA James ${ }^{1}$, IG Campbell ${ }^{1}$ \\ From Familial Aspects of Cancer 2011 Research and Practice: A combined meeting of kConFab, Australian \\ Breast Cancer Family Study, Australian Colorectal Cancer Family Study, Australian Ovarian Cancer Study, \\ Family Cancer Clinics of Australia and New Zealand and kConFab \\ Kingscliff, Australia. 23-26 August 2011
}

The recent identification of a biallelic $R A D 51 C$ (FANCO) mutation in a family with a Fanconi Anemialike disorder led to its examination in a large hereditary breast and ovarian cancer case-control candidate study (Meindl, et al., 2010; Vaz, et al., 2010). Meindl et al. identified six independent pathogenic monoallelic mutations. Interestingly, these mutations were identified exclusively within 480 families with breast and ovarian cancer (frequency 1.3\%) but not among any of the 620 families with breast cancer only. In most subsequent studies, the mutation frequency has been found to be lower than $1.3 \%$, with only three additional truncating mutations being identified in five families among more than 729 ovarian cancer families (with or without breast cancer) (Akbari, et al., 2010; Pang, et al., 2011; Pelttari, et al., 2011; Romero, et al., 2011; Silvestri, et al., 2011; Wong, et al., 2011; Zheng, et al., 2010). Despite the presence of breast cancer in 10 of the 15 RAD51C mutation positive families reported to date, analysis of more than 1,373 breast cancer-only families by eight studies collectively has not identified any additional families with truncating $R A D 51 C$ mutations. Therefore, while evidence of a causative role for $R A D 51 C$ in breast and ovarian or ovarian only cancer families (HBOC) is convincing, albeit with low prevalence, its role in breast cancer only $(\mathrm{HBC})$ families remains unclear.

To provide more definitive data on the incidence of RAD51C mutations in hereditary breast and ovarian families, we utilised high resolution melt (HRM) analysis

${ }^{1}$ Peter MacCallum Cancer Centre, East Melbourne, Australia

Full list of author information is available at the end of the article to screen for germline mutations in all coding exons of $R A D 51 C$ in index cases from 1,388 non-BRCA1, non$B R C A 2$ high risk Australian $\mathrm{HBC}$ and $\mathrm{HBOC}$ families, and 427 controls. In addition, the contribution of $R A D 51 C$ in unselected ovarian cancer was examined through the analysis of germline DNA from an unselected cohort of 267 ovarian cancer patients.

Analysis of 1,053 HBC and $335 \mathrm{HBOC}$ families, and 267 unselected ovarian cancer cases identified 12 novel heterozygous variants in $R A D 51 C$, three of which were protein truncating, six non-synonymous, one synonymous and two non-coding. Numerous dbSNPs and variants from previous studies were also identified. Two truncating mutations, c.72_73insTGCGG (p.V25CfsX3) and c.397C $>\mathrm{T}$ (p.Q133X), were identified amongst the 1,388 familial cases. Consistent with the previously reported deleterious mutations, both variants were identified in families with at least one report of ovarian cancer. A third truncating variant, c.230delG (p. G77VfsX24), was identified in a high grade serous tumour among the 267 unselected ovarian cancer cases. In silico analyses predict that four missense variants (including two novel variants) are likely to be pathogenic. Our data also provide support for the designation of the previously reported missense variants p.G264S, and possibly p.A126T, as moderate penetrance alleles.

\footnotetext{
Author details

${ }^{1}$ Peter MacCallum Cancer Centre, East Melbourne, Australia. ${ }^{2}$ Queensland Institute of Medical Research, Herston, Australia. ${ }^{3}$ The University of Queensland, Brisbane, Australia. ${ }^{4}$ Monash University, Clayton, Australia. ${ }^{5}$ The
} 
Published: 12 April 2012

doi:10.1186/1897-4287-10-S2-A84

Cite this article as: Thompson et al:: Analysis of RAD51C germline

mutations in high-risk breast and ovarian cancer families and ovarian

cancer patients. Hereditary Cancer in Clinical Practice 2012 10(Suppl 2):A84.

Submit your next manuscript to BioMed Central and take full advantage of:

- Convenient online submission

- Thorough peer review

- No space constraints or color figure charges

- Immediate publication on acceptance

- Inclusion in PubMed, CAS, Scopus and Google Scholar

- Research which is freely available for redistribution

Submit your manuscript at 